\title{
Personal wellbeing and stress coping strategies among nurses working at the departments of anesthesiology and intensive care
}

Satysfakcja osobista i strategie radzenia sobie ze stresem u pielęgniarek pracujących na oddziałach anestezjologii i intensywnej terapii

\section{Lucia Dimunová1 ๑ , Anna Bérešová2 , Jarmila Kristová3 , Ferdinand Mohnyánszki", Jana Michalková'}

'Depatrment of Nursing Care, Faculty of Medicine, Pavol Jozef Šafárik Univerzity in Košice, Slovakia 2Depatrment ov Social and Behavioral Medicine, Faculty of Medicine, Pavol Jozef Šafárik Univerzity in Košice, Slovakia ${ }^{3}$ Faculty of Nursing and Professional Health Studies, Slovak Madical University, Slovakia ${ }^{4}$ Department of Anesthesiology and Intensive Medicine, Louis Pasteur University Hospital in Košice, Slovakia

\author{
CORRESPONDING AUTHOR: \\ Lucia Dimunová \\ Depatrment of Nursing Care, Faculty of Medicine, \\ Pavol Jozef Šafárik Univerzity in Košice, Tr. SNP č.1, Košice Slovakia \\ Tel. +421552343292 \\ e-mail: Iucia.dimunova@upjs.sk
}

STRESZCZENIE

Słowa kluczowe:

ABSTRACT

Key words:

\section{SATYSFAKCJA OSOBISTA I STRATEGIE RADZENIA SOBIE ZE STRESEM U PIELĘGNIAREK PRACUJĄCYCH NA ODDZIALACH} ANESTEZJOLLOGII I INTENSYWNEJ TERAPII

Cel pracy. Ustalenie, jaka jest osobista satysfakcja pielęgniarek w odniesieniu do wybranych zmiennych. Identyfikacja tego, czy satysfakcja osobista ma wpływ na preferencje pielęgniarek w zakresie strategii radzenia sobie ze stresem.

Materiał i metody. Grupa była złożona z 509 pielęgniarek pracujących na oddziałach anestezjologii i intensywnej terapii. Wykorzystaliśmy kwestionariusz Personal Wellbeing Index - Adult (PWI - A) oraz kwestionariusz Coping Strategies (Brief COPE). Dane analizowano za pomocą metod statystyk opisowych i indukcyjnych.

Wyniki. Subiektywna ocena satysfakcji pielęgniarek kształtowała się na poziomie $60-70 \%(60,85 ; S D \pm 12,47)$. Wiek i stan cywilny nie potwierdzały istotnego wpływu na satysfakcję osobistą pielęgniarek, w przeciwieństwie do stażu i edukacji. Najniższe zadowolenie osobiste wymieniały pielęgniarki w związku z ich obawami o przyszłość. Wykazano związek między strategiami radzenia sobie a osobistą satysfakcją, szczególnie w kwestiach satysfakcji z relacji osobistych i satysfakcji z życia w społeczności. Pielęgniarki stosowały zarówno adaptacyjne, jak i nieadaptacyjne strategie radzenia sobie.

Wnioski. Istotne jest monitorowanie osobistej satysfakcji pielęgniarek i stosowanie strategii radzenia sobie, które mogą mieć wpływ na wyniki pracy pielęgniarek, bezpieczeństwo i jakość świadczonych usług zdrowotnych.

satysfakcja osobista, strategie radzenia sobie ze stresem, pielęgniarka, intensywna terapia

\section{PERSONAL WELLBEING AND STRESS COPING STRATEGIES AMONG NURSES WORKING AT THE DEPARTMENTS} OF ANESTHESIOLOGY AND INTENSIVE CARE

Aim. To investigate the personal wellbeing of nurses in relation to selected variables. Then to explore whether personal wellbeing has any impact on preference for stress coping strategies.

Material and methods. The sample consisted of 509 nurses working at the Department of Anaesthesiology and Intensive Medicine. We used the Personal Wellbeing Index - Adult (PWI - A) scale and coping strategies (Brief COPE) questionnaire. Data were analyzed using the methods of descriptive and inductive statistics.

Results. Subjective perception of personal wellbeing was assessed at the score $60-70 \%(60.85 ; S D \pm 12.47)$. The research revealed that age and marital status had no significant impact on wellbeing in contrast to the length of work experience and education level. The lowest scores of personal wellbeing among nurses were detected in connection with their concerns regarding their future security. Nurses utilized both adaptive and maladaptive coping strategies. The study pinpointed the connection between coping strategies and personal wellbeing, in particular, in the domain of satisfaction with personal relationships and satisfaction with community connectedness.

Conclusions. Monitoring the personal wellbeing of nurses and utilizing stress coping strategies proved to be important, because these may have an impact on the work performance of nurses, personal safety, and quality of health work experiences they provide. personal satisfaction, coping strategies, nurses, intensive care 


\section{INTRODUCTION}

The research on the working environment of the last decade has concentrated mainly on psychosocial risks at work, especially on stress, which was identified as one of the key factors in maintaining health and safety at work [1]. According to the WHO [2], work-related stress is a response people may experience when exposed to work demands and pressure that do not correspond to their skills and knowledge and which challenge their ability to cope with such work-related stress. Tomasina [3] states that work-related stress is accountable for the reduced quality of professional performance, satisfaction and wellbeing of individuals, as well as for the stagnation of their personal development, absences at work, and decrease in the quality of health services they provide. As for the working environment, departments of intensive care can be characterized as highly systematic, demanding and constantly changing [4]. They typically involve large numbers of patients who are in life-threatening conditions, unforeseeable circumstances, long working hours, a reduced period for care provision, deficiency of human and material resources, demands of family members and close contact with the process of death and dying [5-8]. In order to provide quality nursing care, nurses should be in good physical and psychical condition and are expected to cope well with the workload and work-related stress. Their ability to cope with stress can transpose to their satisfaction with life as a whole. Psychological wellbeing is usually considered to be a combination of positive affective states and functioning with optimal effectiveness [9]. Several studies investigated the impact of wellbeing of nurses working at the departments of intensive care in relation to various parameters of nursing care [10-13].

Response to workload and work-related stress varies from person to person. From the perspective of workload management, different coping strategies can be identified among nurses working in clinical practice which can be either problem-focused or emotion-focused $[14,15]$. Coping can be conceptualized as any cognitive or behavioral effort to master, minimize or tolerate circumstances which individuals perceive as potentially dangerous to their wellbeing [16]. The relation between coping strategies and wellbeing was tackled in some of the studies $[17,18]$.

\section{AIM}

The primary aim of our study was to explore the personal wellbeing among nurses working at the departments of anaesthesiology and intensive care in relation to such variables as age, marital status, education and, length of work experience. Secondly, our objective was to explore whether personal wellbeing may have any impact on the preference for any stress coping strategy.

\section{MATERIAL AND METHODS}

The research sample included 509 nurses working at the departments of anaesthesiology and intensive medicine in the Slovak Republic. The selection of the research sample was based on the following criteria: minimum one-year of work experience at the departments of anaesthesiology and intensive medicine, voluntariness and willingness to cooperate. From the total number of 509 nurses, women represented $94 \%(n=477)$ and men $6 \%(n=32)$. The average age of respondents was $42.12( \pm 9.72)$ years. The average length of work experience of nurses was $16.22( \pm 10.17)$ years. As regards the education of nurses, the sample consisted of $45 \%(n=227)$ nurses with completed secondary education and $55 \%(n=282)$ nurses with university education. In relation to the parameter of marital status, the research sample consisted of $47 \%(n=239)$ married nurses, $35 \%$ $(\mathrm{n}=178)$ single nurses, $14 \%(\mathrm{n}=72)$ divorced nurses and widows represented the smallest part $4 \%(n=20)$.

The method of data collection involved two questionnaires: 1. Personal Wellbeing Index - Adult (PWI-A); 2. Coping Strategies scale (Brief COPE). Data collection also included sociodemographic variables, such as age, marital status, education level and length of work experience.

1. The measurement of personal wellbeing was grounded on the PWI - A scale. This scale separately assesses the global item that indicates the total satisfaction with life followed by eight items that correspond to the individual domains of life. The respondents assess their satisfaction within an individual domain making use of the $0-10$ end-defined ( 0 represents no satisfaction with life at all; 5 represents neutral satisfaction and 10 represents completely satisfied with life) sentences. When the questionnaire is evaluated, the scores obtained within individual items are converted into the standard 0-100 scale format. The aim is to obtain a percentage of the maximum scale. We used a questionnaire in Slovak language. The Slovak version was elaborated by Džuka (2002) and is in the public domain on the website of the Australian Centre on Quality of Life [19]. Cronbach's alfa coefficient of the PWI - A scale in our research represents the value 0.734 .

2. The Brief COPE scale is a revised and reduced version of the original COPE scale [20]; it consists of 28 items divided into 14 subscales where each scale comprises two items. The respondents choose their responses along a four-point Likert-type scale (1 - no; 2 - rather not; 3 rather yes; 4 - yes). Hence, the higher the score on this scale, the higher the level of coping by the respondent. Subscales, or alternatively, coping strategies, are then divided into adaptive (problem-focused or emotion-focused) and maladaptive (avoidance-focused). We used a questionnaire in Slovak language. In order to ensure the correct translation of the methodology into Slovak, we asked a professional institution, the Department of English and American Studies of the Pavol Jozef Šafárik University in Košice, Slovakia for a double translation and a subsequent discussion. Cronbach's alfa coefficient in the Brief COPE scale in our research sample is 0.753 .

The questionnaires were self-completed by the nurses online on the website of the professional organization of the Slovak Chamber of Nurses and Midwives after entering their registration number. Nurses were notified of the possibility to participate in the research by email messages delivered 
to the official email addresses they have as members of the organization. Data collection was carried out during the period from July to December 2017. Data processing made use of the SPSS 24.0 program utilizing the methods of descriptive (means, standard deviation, absolute and relative frequencies) and inductive statistics (ANOVA test, Spearman's correlation test, Pearson's correlation test). The statistical significance was set at the 0.05 level.

\section{RESULTS}

Our analysis of the results was focused on the assessment of the personal wellbeing (Tab. 1). Subjective assessment of personal wellbeing of nurses fluctuated around $60-70$ of the maximum $100 \%$ scale $(60.85, \mathrm{SD} \pm 12.47)$. In relation to individual domains of satisfaction with life, the values for nurses averaged at about $70-80 \%$, concretely, in the domains of personal health, achievement in life, personal relationships, community connectedness, religion and spirituality, total satisfaction with life.

Table 2. shows the relations between sociodemographic variables and individual domains of personal wellbeing. Our researched sample of nurses demonstrated statistically significant correlations only with regards to the length of work experience, education level and individual domains of PWI-A. Positive correlations were manifested between the length of work experience of nurses and satisfaction with health ( $r s=0.138 ; \mathrm{p}<0.01)$, achievement in life $(\mathrm{rs}=0.091 ; \mathrm{p}<0.05)$ and spirituality and religion $(\mathrm{rs}=0.118$; $\mathrm{p}<0.01$ ). The findings manifest that satisfaction of nurses in individual domains increases in parallel with the length of work experience. A statistically significant negative correlation was detected between the domain of future security and the length of work experience ( $r s=0.149 ; \mathrm{p}<0.01)$, an education level ( $r s=0.094 ; \mathrm{p}<0.05)$. The satisfaction of nurses with their future security decreases with longer work experience and higher educational levels.

The following section was designed to determine whether personal wellbeing may have any impact on the preference for any stress coping strategy. The research sample of nurses revealed a statistically significant negative correlation between adaptive coping strategies and satisfaction with personal relations and instrumental support $(\mathrm{r}=-0.103 ; \mathrm{p}<0.05)$. With the decreasing satisfaction in this domain of life, the tendency to prefer the coping strategy of instrumental support increases. Statistically significant negative correlations were discovered between life satisfaction with part of your community connectedness and coping strategies of active coping $(r=-0.090 ; p<0.05)$ and planning $(\mathrm{r}=-0.110 ; \mathrm{p}<0.05)$. With the decreasing satisfaction in this domain, nurses are more inclined to opt for coping strategies of active coping and planning. A significant negative correlation was observed between the coping strategy of humor and wellbeing in the domain of future security $(r=-0.010 ; \mathrm{p}<0.05))$ and religion and spirituality $(\mathrm{r}=-0.102 ; \mathrm{p}<0.05)$. Nurses demonstrated a preference for this coping strategy with regards to the decreasing future security and satisfaction with spirituality and religion (Tab. 3).
Tab. 2. Correlations between sociodemographic variables and personal wellbeing

\begin{tabular}{|l|c|c|c|c|}
\hline Domains of PWI & Age & $\begin{array}{c}\text { Marital } \\
\text { status }\end{array}$ & Education & $\begin{array}{c}\text { Length of work } \\
\text { experience }\end{array}$ \\
\hline Standard of living & -0.063 & -0.030 & -0.053 & -0.023 \\
\hline Health & 0.005 & -0.023 & 0.060 & $\mathbf{0 . 1 3 8 ^ { * * }}$ \\
\hline $\begin{array}{l}\text { Achievements } \\
\text { in life }\end{array}$ & -0.047 & 0.002 & -0.023 & $\mathbf{0 . 0 9 1 ^ { * }}$ \\
\hline $\begin{array}{l}\text { Personal } \\
\text { relationships }\end{array}$ & 0.021 & 0.022 & -0.005 & 0.046 \\
\hline Personal safety & -0.075 & -0.018 & -0.045 & -0.062 \\
\hline $\begin{array}{l}\text { Part of your } \\
\text { community }\end{array}$ & 0.007 & 0.003 & -0.071 & 0.057 \\
\hline Future security & -0.022 & -0.014 & $-\mathbf{0 . 0 9 4}$ & $-\mathbf{0 . 1 4 9 * *}$ \\
\hline $\begin{array}{l}\text { Religion and } \\
\text { spirituality }\end{array}$ & -0.030 & 0.027 & 0.021 & $\mathbf{0 . 1 1 8 ^ { * * }}$ \\
\hline $\begin{array}{l}\text { Global life } \\
\text { satisfaction }\end{array}$ & 0.028 & -0.001 & -0.018 & 0.016 \\
\hline PWI total score & -0.034 & 0.002 & -0.053 & 0.040 \\
\hline
\end{tabular}

${ }^{*} p<0.05 ;{ }^{*}{ }^{*}<0.01 ;$ Spearman's $r$; PWI - Personal Well-being Index

Tab. 1. Well-being of nurses

\begin{tabular}{|l|l|}
\hline \multicolumn{1}{|c|}{ Domains of PWI } & Mean ( $\mathbf{\text { SD }}$ ) \\
\hline Standard of living & $61.32 \pm 23.97$ \\
\hline Health & $79.12 \pm 21.03$ \\
\hline Achievements in life & $72.95 \pm 18.12$ \\
\hline Personal relationships & $75.23 \pm 19.78$ \\
\hline Personal safety & $68.07 \pm 22.37$ \\
\hline Part of your community & $74.34 \pm 18.64$ \\
\hline Future security & $\mathbf{3 6 . 5 0} \pm 35.09$ \\
\hline Religion and spirituality & $70.33 \pm 25.73$ \\
\hline Global life satisfaction & $70.61 \pm 18.87$ \\
\hline PWI total score & $60.85 \pm 12.47$ \\
\hline
\end{tabular}

SD - standard deviation; PWI - Personal Well-being Index

Tab. 3. Correlations between PWI personal wellbeing and adaptive coping strategies

\begin{tabular}{|l|c|c|c|c|c|c|c|c|}
\hline \multirow{2}{*}{$\begin{array}{l}\text { Domains of } \\
\text { PWI }\end{array}$} & \multicolumn{7}{|c|}{ Adaptive coping strategies } \\
\cline { 2 - 8 } & AC & RES & IS & PR & PL & HU & ACC & RS \\
\hline $\begin{array}{l}\text { Standard of } \\
\text { living }\end{array}$ & -0.049 & -0.026 & 0.002 & -0.052 & -0.023 & -0.074 & -0.053 & -0.021 \\
\hline Health & 0.004 & -0.018 & -0.032 & 0.007 & -0.029 & 0.067 & -0.074 & -0.052 \\
\hline $\begin{array}{l}\text { Achievements } \\
\text { in life }\end{array}$ & 0.030 & -0.008 & 0.016 & -0.044 & -0.006 & 0.051 & -0.003 & -0.014 \\
\hline $\begin{array}{l}\text { Personal } \\
\text { relationships }\end{array}$ & 0.005 & 0.029 & $-\mathbf{0 . 1 0 3 *}$ & -0.036 & 0.022 & 0.022 & 0.012 & 0.005 \\
\hline $\begin{array}{l}\text { Personal } \\
\text { safety }\end{array}$ & 0.020 & 0.055 & 0.066 & 0.001 & -0.041 & -0.44 & -0.015 & -0.013 \\
\hline $\begin{array}{l}\text { Part of your } \\
\text { community }\end{array}$ & $-\mathbf{0 . 0 9 0 *}$ & -0.020 & -0.041 & -0.085 & $-\mathbf{0 . 1 1 0 *}$ & 0.053 & -0.054 & -0.048 \\
\hline Future security & -0.007 & 0.010 & 0.065 & -0.071 & -0.062 & $-\mathbf{0 . 0 1 0 *}$ & -0.034 & 0.024 \\
\hline $\begin{array}{l}\text { Religion and } \\
\text { spirituality }\end{array}$ & 0.005 & 0.011 & 0.021 & -0.017 & -0.027 & $-\mathbf{0 . 1 0 2 *}$ & -0.005 & 0.081 \\
\hline $\begin{array}{l}\text { Global life } \\
\text { satisfaction }\end{array}$ & 0.014 & 0.007 & -0.024 & -0.037 & -0.017 & 0.024 & -0.024 & -0.050 \\
\hline PWl total score & 0.001 & 0.001 & 0.005 & -0.061 & -0.064 & -0.050 & -0.040 & 0.012 \\
\hline
\end{tabular}

${ }^{*} \mathrm{p}<0.05$; Pearsons'r; PWI - Personal Well-being Index;

AC - Active Coping; RES - Receiving Emotional Support; IS - Instrumental support; PR - Positive Reframing

$\mathrm{PL}$ - Planning; HU - Humor; ACC - Acceptance; RS - Religiosity and Spirituality 
Considering the maladaptive coping strategies, statistically significant negative correlations were identified between satisfaction with personal relationships and coping strategies of substance abuse $(\mathrm{r}=0.094 ; \mathrm{p}<0.05)$, disengaged behavior $(\mathrm{r}=-0.098 ; \mathrm{p}<0.05)$, self-blaming $(\mathrm{r}=-0.106 ; \mathrm{p}<0.05)$, which evidences the fact that with the decreasing satisfaction in this domain of life, the nurses' preference for workload and stress coping strategies increases. Self-blaming as a coping strategy is utilized by nurses demonstrating decreasing satisfaction with personal relationships $(\mathrm{r}=-0.106 ; \mathrm{p}<0.05)$, community connectedness $(\mathrm{r}=-0.91 ; \mathrm{p}<0.05)$, and PWI total score $(\mathrm{r}=-0.101 ; \mathrm{p}<0.05)$ (Tab. 4).

Tab. 4. Correlations between PWI personal wellbeing and maladaptive coping strategies

\begin{tabular}{|l|c|c|c|c|c|c|}
\hline \multirow{2}{*}{$\begin{array}{l}\text { Domains of } \\
\text { PWI }\end{array}$} & \multicolumn{6}{|c|}{ Maladaptive coping strategies } \\
\cline { 2 - 7 } & SD & DE & SA & DB & VE & SB \\
\hline $\begin{array}{l}\text { Standard of } \\
\text { living }\end{array}$ & -0.054 & 0.007 & 0.046 & -0.044 & -0.010 & -0.037 \\
\hline Health & 0.026 & 0.044 & 0.066 & -0.027 & -0.041 & -0.017 \\
\hline $\begin{array}{l}\text { Achievements } \\
\text { in life }\end{array}$ & 0.009 & 0.026 & 0.087 & -0.079 & 0.005 & -0.050 \\
\hline $\begin{array}{l}\text { Personal } \\
\text { relationships }\end{array}$ & -0.033 & -0.037 & $\mathbf{0 . 0 9 4 ^ { * }}$ & $-\mathbf{- 0 . 0 9 8 *}$ & -0.002 & $-\mathbf{0 . 1 0 6 *}$ \\
\hline $\begin{array}{l}\text { Personal } \\
\text { safety }\end{array}$ & 0.014 & 0.073 & 0.045 & 0.015 & 0.028 & -0.055 \\
\hline $\begin{array}{l}\text { Part of your } \\
\text { community }\end{array}$ & -0.11 & 0.034 & 0.042 & -0.052 & -0.032 & $-\mathbf{0 . 0 9 1 *}$ \\
\hline Future security & 0.053 & 0.024 & 0.020 & -0.023 & 0.008 & -0.064 \\
\hline $\begin{array}{l}\text { Religion and } \\
\text { spirituality }\end{array}$ & 0.029 & 0.009 & -0.087 & 0.053 & 0.005 & -0.087 \\
\hline $\begin{array}{l}\text { Global life } \\
\text { satisfaction }\end{array}$ & -0.022 & 0.010 & 0.019 & -0.066 & 0.002 & -0.028 \\
\hline PWI total score & 0.020 & 0.027 & 0.012 & -0.035 & -0.004 & $-\mathbf{0 . 1 0 1 *}$ \\
\hline
\end{tabular}

${ }^{*} \mathrm{p}<0.05$; Pearsons $r$; PWI - Personal Well-being Index

SD - Self-distraction; DE - Denial; SA - Substance Abuse; DB - Disengaged Behavior; VE - Venting; SB - Self-blaming;

\section{DISCUSSION}

Chronic and excessive stress appears to be an indispensable element of life in contemporary society [21]. The work of nurses in the departments of anaesthesiology and intensive medicine is very specific, physically and psychologically demanding. Our primary objective was to explore how nurses working in these departments perceived their personal wellbeing and which factors were decisive for their personal wellbeing. The relations between wellbeing and coping strategies were investigated separately.

The PWI global score in our researched sample of nurses represents 60.85 maximum in the $100 \%$ scale, which is much higher than the score for nurses working in the Intensive Care Units $(\mathrm{n}=94)$ in Slovakia detected six years ago $49.90 \%$ [14]. The lowest score of personal wellbeing 36.50 was identified in our sample of nurses in the domain of future security, similarly to the findings of other study [11-13]. These results appear to be alarming. The analyses study (Kwiecień-Jaguś et al., 2018) confirm that high job dissatisfaction among the nursing staff is connected with bad internal organization of the workplace, conflicts with supervisors, and a lack of understanding between nurses and their supervisors [22]. Gurková, et al. [12] conducted an international cross-sectional study aimed at subjective wellbeing of nurses ( $n=1055)$ utilizing PWI-A scale and identified the score of satisfaction with life at $60-70 \%$ maximum of $100 \%$ scale which corresponded with our findings.

Our research revealed that length of work experience and education level appeared to be the factors that had an impact on PWI. The satisfaction of nurses with the domains of personal health, achievement in life and spirituality and religion grew concurrently with the length of work experience. Nurses with a higher level of education and longer work experience expressed their concerns for future security. The authors Gurková et al. [12] maintain that the personal wellbeing of nurses is negatively associated with the length of work experience (aging nurses consider the option of quitting their job and going abroad). Correlations between age and PWI in our research sample proved insignificant in comparison with the study of Burešová, Jarošová [11], in which satisfaction with life received the highest scores from the youngest nurses, and similarly, higher education correlated with the higher PWI.

The relation between coping strategies and wellbeing among nurses is analyzed in the study of Loukzadech, Baffroi [18]. Considering the fact that adaptive coping strategies are effective for the resolution of conflicts and work-related stress and maladaptive are connected with unfavorable health conditions, it is possible to evaluate coping strategies as effective. In a similar vein, the findings of the study by Lee et al. [17] point to the fact that adaptive coping strategies have a significant positive impact on the wellbeing of nurses. Authors Zhou, Gong [23] say that active coping was positively related to resource and environmental problems, and passive coping was positively related to workload and time pressure, and to interpersonal relationship and management issues. Our researched sample of nurses working in the departments of anaesthesiology and intensive medicine also showed correlation between coping strategies and personal wellbeing, in particular, in the domains of satisfaction with personal relationships and satisfaction with community connectedness. Nurses utilized adaptive coping strategies: active coping, planning, instrumental support and humor and maladaptive coping strategies of substance abuse, disengaged behavior and self-blaming.

The significance of the PWI assessment is also pinpointed by the study which comprised the sample of 2075 nurses [10]. The authors state that the lower the PWI score among the nurses, the more susceptible the nurses are to burnout syndrome and extreme fatigue. Meng et al. [24] confirm that the higher the wellbeing of nurses, the less susceptible the nurses are to burnout syndrome. The study of Yermilova et al. [25] arrives at the conclusion that psychological wellbeing plays a vital role in personal growth. It is a constituent part of the formation of motivation for self-realization. Positive wellbeing may improve the working environment of nurses which has a positive impact on the provision of quality nursing care [17]. 


\section{Limitation of study}

Certain limitations were inherent to the nature of our research. The size of the sample of nurses in relation to the total number of nurses in Slovakia can be considered a limitation of the study. The fact that the questionnaire was completed only by nurses, who were interested in the monitored issue, can also be considered a limitation

\section{CONCLUSIONS}

The research yielded several interesting findings. Subjective assessment of personal wellbeing of nurses fluctuated around $60-70 \%$. In domains of PWI standard of living it was mean score 61.32 and personal safety, it was 68.07. Mean other domains of PWI such as global life satisfaction, religion and spirituality, part of your community, personal relationships, and achievements in life were from 70.61 to 75.23 . The highest mean score of nurses reported the health domain. The lowest scores of personal wellbeing were detected among nurses in the domain of future security.

Selected sociodemographic variables, such as the age of nurses and their marital status, had no impact on the assessment of personal wellbeing in the research sample. Length of work experience and education level had a positive impact on the majority of domains of personal wellbeing.

The personal wellbeing of nurses influences the choice of adaptive and maladaptive coping strategies. In the domains of personal relationships, part of community connectedness and PWI total score, a significant relation was identified in connection to the use of adaptive coping strategies: active coping, planning, instrumental support and humor and maladaptive coping strategies: substance abuse, disengaged behavior a self-blaming.

The following implications arise on the basis of our findings:

1. Focus on personnel management, especially, on personal relations in the workplace (effective conflict resolution, teambuilding, couching, and supervision);

2. Development and promotion of stress coping strategies among nurses at the workplace and also during vocational training of nurses (pre-graduate education);

3. Promoting discussion in the professional community and identification of the causes of subjectively demonstrated insecurity and concerns of nurses with regards to their future.

\section{ORCID}

Lucia Dimunová (iD) https://orcid.org/0000-0002-5577-6135

\section{REFERENCES}

1. Kortum E, Leka S, Cox T. Psychosocial risks and work-related stress in developing countries: health impact, priorities, barriers and solutions. International Journal of Occupational Medicine and Environmental Health. 2010; 23(3): 225-238.

2. World Health Organization. Stress at the workplace. 2018.

3. Tomasina F. Problems of work world and its impact on health: Current financial crisis. Revista de Salud Publica. 2012; 14(1): 56-67.
4. Crilly J, Greenslade J, Lincoln C, et al. Measuring the impact of the working environment on emergency department nurses: A cross-sectional pilot study. International Emergency Nursing. 2017; 31: 9-14.

5. Červený M, Siaki A, McGee P, Kilíková M. Perception of European nurses of culturallyappropriate health care - A cross-sectional study. Medycyna Ogólna i Nauki o Zdrowiu. 2019; 25(1): 27-32.

6. Obročníková A, Majerníková L', Gresš-Halász B. Syndróm vyhorenia ako determinant pracovnej výkonnosti sestier. Pracovní lékařství. 2019; 71(1-2): 35-41.

7. Zamboriova M, Simočková V. Psychická zátaž zdravotníckych profesionálov pracujúcich v hospicoch. Zborník: Ošetrovatel'stvo - tradície a perspektívy. Pieštáany: 2016, s. 325-336

8. Duffy E, Avalos G, Dowling M. Secondary traumatic stress among emergency nurses: a cross-sectional study. International Emergency Nursing. 2015; 23(2): 53-58.

9. Winefield HR, Gill TK, Taylor AW, et al. Psychological well-being and psychological distress: is it necessary to measure both?. Psych. Well-Being. 2012; 2, 3.

10. Dyrbye LN, Johnson PO, Johnson LM, et al. Efficacy of the well-being index to identify distress and stratify well-being in nurse practitioners and physician assistants. Journal of the American Association of Nurse Practitioners. 2019; 31(7): 403-412.

11. Burešová $Z$, Jarošová $D$. Quality of life among hospital nurses. Ošetrovatel'stvo: teória, výskum, vzdelávanie. 2015; 5(1): 13-17.

12. Gurková E, Žiaková K, Sováriová Soósová $M$, et al. Subjective well-being and intention to leave among (zech and Slovak nurses. Central European Journal of Nursing and Midwifery. 2013; 4(4): 664-669.

13. Gurková E, Macejková S. Psychological strain and depressive symptomatology between nurses. Central European Journal of Nursing and Midwifery. 2012; 3(1): 326-334.

14. Dimunová L. Coping strategies in clinical practice among nurses. Zdravotnícke listy. 2014; 2(1): 18-24.

15. Ramezanli S, Koshkaki AR, Talebizadeh M, et al. A study of the coping strategies used by nurses working in the intensive care units of hospitals affiliated to Jahrom University of medical sciences. International Journal of Current Microbiology and Applied Sciences. 2015; 4(4): 157-163.

16. Folkman S, Lazarus RS. An analysis of coping in a middle-aged community sample. Journal Health Social Behavior. 1980; 21(3): 219-239.

17. Lee TS, Tzeng WC, Chiang HH. Impact of coping strategies on nurses' well-being and practice. Journal of Nursing Scholarship. 2019; 51(2): 195-204.

18. Loukzadeh Z, Bafrooi MN. Association of coping style and psychological well-being in hospital nurses. Journal of Caring Sciences. 2013; 2(4): 313-319.

19. Džuka J. Australian Centre Quality of Life. Translation of the Personal Wellbeing Index (PWI). 2002. http://www.acqol.com.au/uploads/pwi-a/pwi-a-slovakia.pdf.

20. Carver CS. You want to measure coping but your protocol's too long: consider the Brief COPE. International Journal of Behavioral Medicine. 1997; 4(1): 92-100.

21. Szadowska-Szlachetka Z, Drzewi M, Łuczyk M, et al. Coping with stress by Medical University students. Pielęgniarstwo XXI wieku/Nursing in the 21st Century. 2020; 19(2): 95-101.

22. Kwiecień-Jaguś K, Mędrzycka-Dąbrowska W, Chamienia A, Kielaite V. Stress factors vs. job satisfaction among nursing staff in the Pomeranian Province (Poland) and the Vilnius Region (Lithuania). Annals of Agricultural and Environmental Medicine. 2018; 25(4): 616-624.

23. Zhou H, Gong YH. Relationship between occupational stress and coping strategy among operating theatre nurses in China: a questionnaire survey. Journal of Nursing Management. 2015; 23, 96-106.

24. Meng R, Luo Y, Liu B, et al. The Nurses' Well-Being Index and Factors Influencing This Index among Nurses in Central China: A Cross-Sectional Study. PLOS ONE. 2015; 10(12): e0144414.

25. Yermilova VV, Loktionova YN, Smirnov AV, et al. The development of a personal wellbeing index - indicator of the life satisfaction. Revista. Espacios. 2019; 40(25): 16.

Manuscript received: 08.11 .2020

Manuscript accepted: 13.01.2021

Translation: Barbara Mitríková CJP - Linguage Training Center, Pavol Jozef Šafárik Univerzity in Košice, Slovakia 